\title{
SMK Teacher Quality Improvement Through Training Development And Packaging Device Based Learning Curriculum 2013
}

\author{
Gede Widay ana \\ Universitas Pendidikan Ganesha \\ Jl Udayana Singaraja,Indonesia \\ gedewidayana@gmail.com
}

\begin{abstract}
Enforcement of the curriculum in 2013 for elementary, junior high, high school / vocational school from 2013 (pilot project) and is planned to be used nationally by 2015 is a challenge faced by the vocational school teachers in the district of Kintamani. To improve the quality and teachers' academic qualifications and skills, Bangli local government has made various efforts, such as helping to further study on teachers who do not graduate, training, seminars and other scientific activities. Factually problem principles that experienced by the teachers of vocational schools in the district of Kintamani today is related to the ability to implement the curriculum in 2013 in accordance with its duties, has not understood the nature of the curriculum in 2013, the lack of capacity and skills of teachers in translating the vision and mission of the curriculum in 2013 , due to the lack of adequate training, the lack of ability of teachers to develop and package the lesson plan in accordance with the curriculum in 2013 and the lack of ability of teachers to develop the evaluation model in line with the curriculum in 2013. Based on the identification of these problems, the main problems are going to look for solutions in this community service is how do improve the knowledge and skills of teachers of vocational schools in the district of Kintamani develop and package a learning according to the curriculum in 2013.
\end{abstract}

Keyword: Training, Curriculum 2013.

\section{INTRODUCTION}

Geographically Kintamani is the largest subdistrict of the four districts in the regency of Bangli. Conditions hilly area and the distance apart between one village to village, making the Kintamani area experiencing dropout rates are highest in Bangli regency. On the other hand, of the 14 vocational schools in Bangli, 3 of which are in the district of Kintamani. (Bangli dalam angka, 2013). Factually, the principle problem faced by vocational high school teachers in the district of Kintamani today is related to the ability to implement the curriculum in 2013 in accordance with pitrahnya. The teachers admit, curriculum change so quickly from the 2004 curriculum, the 2006 curriculum and the 2013 curriculum, made a vocational secondary school teachers in the district of Kintamani "confusion". The implication, the vocational high school teachers in the district of Kintamani has not "understand" the nature of the curriculum in 2013, the development and packaging of learning implementation plan (RPP), a model of learning and development model of evaluation. According Budiningsih (2004: 96) one of the foundations on which to implement the learning process to fit the needs of learners and the purpose of education is to develop the curriculum through a learning device that will be used by teachers. By learning tools teachers will understand the direction development and learning goals and targets to be achieved in learning. On the other hand with a decentralized enforcement of teacher curriculum not only as implementing the curriculum but also as implementers and developers of the curriculum so that the teacher is a life curriculum (Sayodih, 1997: 23). As the curriculum of course, the success of a life curriculum is determined by the ability of teachers in developing the curriculum through learning tools that will be used by the teacher in realizing the learning process.

Judging from academic qualifications vocational teachers in the district have average Kintamani S1 degree (bachelor). To improve teacher's academic qualifications and skills, Bangli local government has made various efforts, such as helping to further study on teachers who have not graduate, training, seminars and other scientific activities. This is because teachers are the main motor driving the advancement of education. In the 2013 curriculum, teachers hold a strategic role, as a designer, implementer and as an evaluator for the progress of students (Curriculum Training Material in 2013). 
Surapranata (2004: 1), which says that the curriculum, the learning process and a three-dimensional evaluation of the very important dimension in education to be implemented by the teacher. The curriculum is an elaboration of educational goals that underlie learning programs must be translated by the teacher (life curriculum). The learning process was an attempt by teachers to achieve the objectives that were defined in the curriculum. While evaluation is an activity undertaken to assess the success or failure of the learning process.

Based on the situation analysis and empirical conditions above, the problems faced by the teachers of vocational schools in the district of Kintamani is: not yet understood the nature of the curriculum in 2013, lack of capacity and skills of teachers in translating the vision and mission of the curriculum in 2013, due to the lack of training adequate, the lack of ability of teachers to develop and package the lesson plan in accordance with the curriculum in 2013 and the lack of ability of teachers to develop the evaluation model in line with the curriculum in 2013. Based on the identification of these problems, the main problems are going to look for solutions in this community service is how to improve the knowledge and skills of teachers of vocational schools in the district of Kintamani develop and package a learning according to the curriculum in 2013.

\section{METHOD AND DISCUSSION}

\section{A. Development and packaging oflearning devices of Vocational High School.}

Based on changes in curriculum 2013 there were some matters of principle that teachers to be able to implement the curriculum in 2013 well, particularly with regard to development of learning tools, the implementation process of learning to the learning evaluation process. Learning activities is an educational process that provides opportunities for learners to develop their potential into an increasing ability in the attitude, knowledge and skills needed to live and community, nation and contribute to the welfare of nation and state life. Therefore, learning activities geared to empower all learners be expected competencies. Learning strategy is used to achieve competence according to the curriculum of 2013 so that learners become independent. Also developed competencies such as leadership, cooperation, independence, empathy, solidarity, creativity, life skills and tolerance of learners. Therefore learning activities should be (1) student center, (2) learning fun and challenging, (3) developing students' creativity,
(4) learning is filled with logic, ethics, aesthetic value, and kinestetika, and (5) diverse learning experiences useful to students Here students are expected to find and solve problems with their knowledge and develop with new information gained. Curriculum 2013 adheres to the basic view that knowledge can not be moved away from the teacher to the learner. Learners is a subject that has the ability to actively search for, cultivate, construct and use knowledge. For that learning should be regarding the opportunities given to students to construct knowledge in cognitive processes. In order to truly understand and can apply the knowledge, learners should be encouraged to work to solve problems, find everything for themselves, and strive to realize their ideas. Teachers provide convenience to this process, by developing a learning environment that allows learners to find, implement their own ideas, be aware of and consciously use their own strategies for learning. Teachers develop learning opportunities for learners to pursue a ladder that brings learners higher understanding that was originally done with the help of teachers but increasingly more independent. For learners, learning should be shifted from "told" to "actively seek out". In learning, learners construct knowledge for themselves. For learners, their knowledge is dynamic, evolving from the simple to the complex, from the scope itself and the surrounding toward a broader scope, and from the nature of the concrete to the abstract. As a developing human, learners have been, are, and / or will undergo four stages of intellectual development, namely sensory motors, pre-operational, concrete operational and formal operational. The learning process can also occur as a combination of inner and outer stimuli. In the process of learning, teachers need to develop both a stimulus to yourself every learner. In learning, learners are facilitated to engage actively develop her potential into competence. Teachers provide learning experiences for students to perform a variety of activities that allow them to develop their potentials into the competencies specified in the curriculum documents or more. The learning experience of progressively increasing becoming independent study habits and steady as one of the foundations for lifelong learning. In a learning activity can occur development of attitudes, knowledge, and skills in combination and varying emphasis. Each revision has a different combination and suppression of other learning activities depends on the nature of the charge were studied. Nonetheless, knowledge has always been a driving element for the development of other abilities.

The learning process consists of five basic learning experiences, namely: (1) observed; (2) ask; (3) collecting the information; (4) associate; and (5) communicating. These five basic learning can be 
specified in a variety of learning activities that are listed in the following table:

T ABLE I. FIVE BASIC LEARNING EXPERIENCES

\begin{tabular}{|c|c|c|c|}
\hline $\begin{array}{l}\text { STEP } \\
\text { LEARNING }\end{array}$ & & ACTIVITY & $\begin{array}{l}\text { COMPETENCE } \\
\text { THAT } \\
\text { DEVELOPED }\end{array}$ \\
\hline Observe & & $\begin{array}{l}\text { Reading, } \\
\text { listening, } \\
\text { listening, } \\
\text { viewing } \\
\text { (with or } \\
\text { without the } \\
\text { tool) }\end{array}$ & $\begin{array}{l}\text { Train seriousness, } \\
\text { thoroughness, } \\
\text { seek information }\end{array}$ \\
\hline Ask & & $\begin{array}{l}\text { Ask if there } \\
\text { is something } \\
\text { that has not } \\
\text { been } \\
\text { understood } \\
\text { or ask for } \\
\text { more } \\
\text { explanation. }\end{array}$ & $\begin{array}{l}\text { Developing } \\
\text { curiosity and } \\
\text { building more } \\
\text { creative thinking. }\end{array}$ \\
\hline $\begin{array}{l}\text { Gathering } \\
\text { information } \\
\text { experiment }\end{array}$ & l & $\begin{array}{l}\text { - conducting } \\
\text { experiment } \\
\text { s read } \\
\text { - } \quad \text { rources } \\
\text { other than } \\
\text { textbooks } \\
\text { - observing } \\
\text { the objects } \\
\text { / events / } \\
\text { - activity } \\
\text { - interviews } \\
\text { with } \\
\text { resource } \\
\text { persons }\end{array}$ & $\begin{array}{l}\text { Develop a polite, } \\
\text { respectful, honest, } \\
\text { polite and } \\
\text { meticulous } \\
\text { attitude. }\end{array}$ \\
\hline $\begin{array}{l}\text { associate / } \\
\text { process } \\
\text { information }\end{array}$ & & $\begin{array}{l}\text { - process the } \\
\text { information } \\
\text { already } \\
\text { collected } \\
\text { either } \\
\text { limited } \\
\text { results } \\
\text { gathering } \\
\text { activities / } \\
\text { experiments } \\
\text { would also } \\
\text { observe the } \\
\text { results of } \\
\text { activities and } \\
\text { events to }\end{array}$ & $\begin{array}{l}\text { Develop } \\
\text { ability to work } \\
\text { hard, discipline } \\
\text { with existing } \\
\text { rules, honest, } \\
\text { thorough and } \\
\text { obedient to the } \\
\text { law }\end{array}$ \\
\hline
\end{tabular}

\begin{tabular}{|c|c|c|}
\hline & $\begin{array}{l}\text { gather } \\
\text { information. } \\
\text { - Processing } \\
\text { information } \\
\text { widely to } \\
\text { find } \\
\text { solutions } \\
\text { from } \\
\text { multiple } \\
\text { sources. }\end{array}$ & \\
\hline Communicating & $\begin{array}{l}\text { Submission } \\
\text { of existing } \\
\text { conclusions } \\
\text { based on } \\
\text { observations } \\
\text { made }\end{array}$ & $\begin{array}{lr}\text { Develop } & \text { an } \\
\text { attitude } & \text { of } \\
\text { tolerance, honest, } \\
\text { careful } \\
\text { expressing } \\
\text { opinions } \\
\text { others. }\end{array}$ \\
\hline
\end{tabular}

The first stage in the learning process of planning by the standards of learning are realized with drafting lesson plan (RPP). Which includes (1) subject matter; (2) time allocation; (3) learning objectives, Basic Competencies and performance indicators; (4) Learning method; (5) media, learning resources; (6) Learning Activities; and (7) assessment. RPP development can be done at the beginning of each semester or the beginning of the school year, with the intention that the RPP has been available prior to the beginning of each learning implementation. RPP development performed by the teacher independently and / or together through deliberation EYES teacher lesson (MGMPs) in a particular school is facilitated and supervised by the principal or senior teacher appointed by the school principal. RPP development undertaken by teachers in groups through MGMPs interscholastic or interregional coordinated and supervised by the supervisor or department of education.

With regard to such authority, then the teacher can develop lesson plans. The principles in developing or preparing lesson plans can be described as follows: (1) RPP is made as a form of process design in learning, (2) RPP was developed in accordance with the conditions in the school, (3) Student participation, (4) Student-centered learning process, (5) developing the culture of reading and writing, (6) ) RPP is designed to read reading materials, (7) Responding to questions and responding to students, (8) In RPP designed to provide feedback, remediation, enrichment and strengthening, (9) linkages and integrity, (10) Preparation of RPP (11) applying information and communication technology, and (12) Preparation of RPP by applying information technology and communication in existing schools. 
Based on the rational development of the RPP least contain: (i) the learning objectives, (ii) learning materials, (iii) teaching methods, (iv) learning resources, and (v) assessment. These components are operational manifested in the form of the following formats:

School :

Subjects :

Class / Semester:

Subject matter :

Time Allocation :

A. Core Competence (KI)

B. Basic Competencies and Indicators

1. (KD at KI-1 indicator)

2.

3.

(KD at KI-2 Indicators)

4.

(KD at KI-3 Indicator)

C. Learning Objectives

(KD at KI-4 Indicators)

D. Content of Learning (the details of Subject )

E. Approaches and Methods of Learning

1. Learning Approach

2. Learning Model

3. Learning Method

F. Media, Tools and Learning Resources

1. Media

2. Tool

3. Learning Resources

G. Steps Learning Activities

H. Assessment

\section{CONCLUSIONS}

From the implementation of community service to elementary school teachers in district of Kintamani can be concluded after the training given by expert teams of Undiksha Singaraja, vocational high school teachers began to prepare and package a learning according to the curriculum of 2013. This can be seen from the results of training development and packaging the appropriate curriculum learning device 2013 that they made. Besides the teachers claimed not worry more if they have to implement the curriculum in 2013 because it has been able to make a learning device. There are some benefits gained by teachers, namely (1) they get information that is clear and intact on the nature of the curriculum in 2013, as long as they do not yet know exactly what the nature of the curriculum in 2013, and (2) the teachers obtain a clear picture of how and strategy development and packaging of appropriate curriculum learning device 2013. Teachers also acknowledge that there has been an increase in their insights and skills in understanding the curriculum of 2013 and the development and packaging of learning tools according to the 2013 curriculum. Thus, the vocational school teachers in the district of Kintamani have adequate preparedness and ability to implement the curriculum in 2013 in accordance with nature

\section{REFERENCES}

[1] Budiningsih, A. (2004). Belajar dan Pembelajaran.. Yogyakarta: Rineka Reserved

[2] Bangli regency government. (2013). Bangli dalam Angka. Bangli: Pemda Bangli.

[3] Djohar. (2003). Pengembangan Kurikulum Berbasis Kompetensi Sekolah Menengah Kejuruan. (Dissertation, unpublished). Bandung: PPS UPI.

[4] Hasan. (1992). An Evaluation of the 1975 Senior General Secondary Social Studies Curriculum Implementation in Bandung Municipality. Doctoral dissertation of Macquary University. Unpublished.

[5] Ministry of Education and Culture. (2013). National Education Standards. Jakarta: BPP

[6] Ministry of Education and Culture. (2013). Curriculum Training Materials 2013. Jakarta: MONE

[7] Lasmawan, W. (2010). Education browse Contextual IPSEmpirical Perspectives. Singaraja: Mediakom Indonesia Bali Press.

[8] MaLaughin. (1987). Implementing of ESEA Title I. New York: Columbia University.

[9] Miller, J. and Wayne S. (1985). Curriculum: Perspectives and Practice. New York: Longman.

[10]Nana, S. (2005). Curriculum Development Theory and Practice Year: Bandung: Rosdakarya

11] Surapranata. (2006). Portfolio Assessment. Implementation of Curriculum 2004 Bandung: PT. Youth Rosdakarya.

[12] Suastika. (2006). Delivering Policy Strategy Singaraja As the City of Education (Research Report). Singaraja: Undiksha 